\title{
8. Ett fokus på levd islam bortanför maximalistiska representationer
}

\author{
Jenny Berglund
}

Sammanfattning Forskning om religionsundervisning visar att religioner ofta representeras på ett maximalistiskt sätt som tenderar att förmedla en stereotyp bild av religiösa människor vilket riskerar att leda till fördomar. I kapitlet diskuteras hur ett religionsvetenskapligt perspektiv med fokus på levd religion kan bidra till ett mer nyanserat perspektiv på religion och religiösa människor. Islam används som exempel för att belysa den variation av praktik och tolkningar som förekommer. Det ger också konkreta exempel på den tolkningsvariation som finns bland människor som kallar sig muslimer.

Nyckelord religionsundervisning | islam | maximalist | tolkning | stereotyp

\begin{abstract}
Research on religious education shows that religions are often represented in a maximalist way and tend to convey a stereotypical image of religious adherents. Such presentations lead to stereotypes that are problematic for education. In the chapter, Islam is used as an example to discuss how a study of religions perspective with a focus on lived religion can contribute with more nuanced perspectives. It also provides concrete examples of the variation in interpretation that exists among people who call themselves Muslims.
\end{abstract}

Keywords religious education I Islam I maximalist I interpretation I stereotypical

\section{INTRODUKTION}

De flesta som anser sig tillhöra en eller annan religion är väl medvetna om de variationer i tillhörighet, praktik, hängivenhet och tro som finns inom sin egen tradition: inte alla hinduer upprätthåller en monistisk syn på den ultimata verkligheten; 
inte alla judar följer den hasidiska ortodoxin; och inte alla muslimer ber fem gånger om dagen. Bland kristna finns olika sätt att fasta och bland ateister finns det såväl svaga som starka former av avståndstaganden till religion.

Aktuell forskning visar att i såväl klassrum, som i läroböcker och pedagogiska filmer, finns en tendens att generalisera och stereotypisera religioner genom att lyfta fram de mest hängivna och involverade utövarna - de personer vars religiösa övertygelse genomsyrar samtliga delar av livet och som jag här, i likhet med Bruce Lincoln (2006, s. 5), väljer att kalla maximalister (Berglund 2014a; Härenstam 2006; Otterbeck 2005; Panjwani \& Revell 2018; Tägt 2018). ${ }^{1}$ Utöver detta finns också en tendens i samhället att människor "religiosifieras", det vill säga att de handlingar de utför och värderingar de har hänvisas till deras religiösa identitet, inte till det faktum att de är söner, fotbollsspelare, mödrar, hipsters eller kriminella (Berglund, 2017; Panjwani, 2017; Panjwani \& Revell 2018). Kombinationen av dessa två tendenser är olycklig, då den bidrar till att reducera människor och klumpa ihop dem. Något som kan bidra till gruppbaserade fördomar.

I det här kapitlet kommer jag diskutera hur ett religionsvetenskapligt perspektiv, med fokus på levd religion, kan bidra till förståelse för den mångfald av tolkningar och praktik vi finner inom religioner. Ett fokus på levd religion innebär att få blick på den variation som förekommer inom religiösa traditioner och ta fasta på vad religiösa människor verkligen gör, men också ge fördjupad förståelse för människors handlanden, tankar och känslor. I stället för att fokusera på dogmer blir plats, rum och materialitet relevant; i stället för att studera religion som abstrakt fenomen studeras hur religion tar plats i världen (McGuire, 2008).

Syftet med kapitlet är dock inte bara att diskutera behovet av förståelse för tolkningar utan även problematisera den förståelse av religion som dominerar våra sekulariserade samhällen. Jag kommer också att föreslå en enkel modell som lärare, och andra, kan använda som utgångspunkt för religion (TTG, se nedan). Genomgående i kapitlet använder jag tolkningar av islam och presentationer av muslimer som exempel.

Varför just islam och muslimer frågar du dig kanske? Först och främst beror det på att det är den religion som jag själv har forskat mest om. En annan anledning är att forskning om såväl svensk som norsk religionundervisning har visat att en del lärare känner en viss osäkerhet kring undervisningen om just islam (Kittelman Flensner, 2015; Toft, 2018). Det är också den religion som hos elever ger mest negativa associationer, får mest kritik, men som å andra sidan upplevs som tabubelagd

1 Härenstam (2006) visar i sin rapport att framställningen av islam har förbättrats i religionskunskapsböcker, men att framställningar som involverar muslimer i samhällskunskap och historieböcker fortfarande framförallt fokuserar på krig och konflikter. 
att kritisera (Kittelman Flensner, 2015, s. 123, 229). Det finns även forskning som visar att det finns tendenser hos vissa lärare att antingen liberalisera och romantisera religioner, däribland islam, eller spä på redan förutfattade meningar (Toft, 2018; Wright, 2004). En förklaring som ofta nämns till att just islam ger negativa associationer sägs vara att islam är den religion som både nationellt och globalt omgärdas av mycket negativ mediebevakning (Axner, 2015; Olseryd et al, 2021). Internationell terrorism med islamiska förtecken har under de senaste decennierna seglat upp som konkurrent till terrorism med andra ideologiska förtecken. Negativa attityder mot islam och muslimer är dock inget nytt, de har funnits i Europa under hundratals år. Den ökande islamofobi vi ser i Europa har idéhistoriska rötterna som går mycket långt tillbaka i tiden (Otterbeck och Bevelander 2006, Gardell 2010, Sorgenfrei 2018). Negativa och stereotypa föreställningar om muslimer bottnar i medeltida kristna idéer som förmedlats vidare genom historien och ändrat form beroende på politiska, sociala och teologiska sammanhang (Gardell 2010; Pickel och Öztürk 2018). För lärare innebär detta en utmaning eftersom de kunskaper om religioner och andra livsåskådningar som eleverna ska förvärva genom skolans undervisning om religion anses viktiga för att skapa ömsesidig förståelse mellan människor. Det finns dock studier som visar att lärares försök på att motverka mediabilden, snarare bidrar till att de befäster bilden (Toft 2018).

\section{PROBLEMET}

Låt oss börja med att ur ett religionsvetenskapligt perspektiv närma oss begreppet religion. Till att börja med är det viktigt att vara medveten om att begreppet religion är komplext och varierar i förhållande till historiskt sammanhang (Larsson \& Sorgenfrei 2019). För många människor som växt upp i västerländskt inspirerad kultur associeras begreppet religion ofta till trosuppfattningar eller helt enkelt tro: ibland kan vi till och med se att orden tro och religion används som synonymer. Oavsett vad vi tror eller inte, påverkar dock religion hur vi äter, umgås, talar, firar högtider och så vidare (Thurfjell, 2016). En förståelse av religion som huvudsakligen handlar om tro behöver dock problematiseras. Att i första hand associera religion med tro innebär att vi riskerar att bli blinda för de levande och levda religionernas mångdimensionella dagliga verklighet (Berglund, 2013; Nilsson, 2018). Tendensen att tala om religion som tro och detta sätt att se på religion är förankrat i protestantisk kristen tradition. Detta märks dock inte bara i själva förståelsen av begreppet religion utan även i hur vi ofta presenterar religioner, så som islam (Berglund, 2013; 2020). Ett religionsvetenskapligt perspektiv med fokus på levd religion ger möjlighet att komma ifrån ett ensidigt fokus på tro, men också att få blick på 
den variation som förekommer inom religiösa traditioner (Ammerman 2016; Britton 2019).

Ett problem för religionsundervisningen som riskerar att bidra till stereotypa bilder av såväl islam som andra religioner är det så kallade Världsreligionparadigmet (Cotter \& Robinsson 2016). Världsreligionparadigmet innebär att religioner i undervisning presenteras som enhetliga boxar som konstruerats på ett bestämt sätt för att gruppera och jämföra religioner efter en bestämd ordning. Problemet med världsreligionparadigmet är dock inte att undervisning behandlar olika religioner, utan de försanthållanden och föreställningar som reproduceras. Religionsvetaren Carole M. Cusack sammanfattar kritiken mot världsreligionsparadigmet: "[It] has been criticized as a simplified, Western-centric, and exclusionary model of religion that closes down interesting avenues of pedagogy and research" (Cusack, 2016, s. 164).

Paradigmet har starkt kritiserats då det reproducerar vilseledande föreställningar om religion som riskerar att generera såväl missuppfattningar som fördomar, något som står i motsats till syftet med religionskunskapsämnet (Owen 2011). Utöver detta riskerar paradigmet att leda till att religioner uppfattas som statiska, monolitiska system där religioner tillskrivs en homogen essens som gör att religionerna själva tillskrivs agens och handlingsförmåga i stället för de religiösa människorna. Från ett religionsvetenskapligt perspektiv innebär ett sådant essentialistiskt synsätt en begränsad syn på religion som blir problematisk i bland annat undervisningssammanhang (Hylén, 2012; Panjwani \& Revell 2018). Här bör tilläggas att utifrån ett religiöst perspektiv, det vill säga ett inifrånperspektiv är religioner till naturen essentialistiska. För den troende själv är den religion hen tillhör just god, bäst, krävande eller rättvis på grund av en tänkt kärna. Självklart har varje enskild troende eller icketroende också rätt att framhålla denna kärna. Från ett religionsvetenskapligt perspektiv är det dock av betydelse att skilja mellan den essentialism som uttrycks av troende och på vilket sätt en religion beskrivs för elever i olika årskurser, då en essentialistisk presentation av religion i undervisning kan bidra till att religion stereotypiseras (Berglund, 2020; 2021). Jan Hjärpe har beskrivit tre uppfattningar om religion som är vanliga och problematiska och som bygger på just en essentialistisk förståelse av religion: a) "att religiös identitet är determinerande, att den avgör hur människor handlar"; b) "att religiösa traditioner är konstanter, oföränderliga, igenkännliga genom århundradena"; c) "att religiösa människor följer religiösa människors utsagor, och att därför vad religiösa ledare säger är representativt för hela gruppen" (Hjärpe, 2012, s. 273). Som religionsvetenskaplig forskning har visat, är dessa uppfattningar felaktiga, vilket innebär att religionskunskapsundervisningen i skolan bör motverka dessa föreställningar (Asprem 2021). 
Ett uttryck för världsreligionparadigmet finner vi till exempel i skolans religionskunskapsböcker där det är vanligt att världsreligioner historiskt och i dag sorteras och presenteras utifrån mannen, boken och tron oavsett vilken religion som presenteras och att denna sortering, med viss modifikation, även behålls i kapitel om icke-religiösa livsåskådningar. I kapitel om kristendom presenteras Jesus, Bibeln och några centrala kristna trossatser, i kapitel om islam: Mohammad, Koranen och trossatser, och så vidare (Berglund, 2014a, s. 6-8). ${ }^{2}$ Tendensen att tala om och förstå religion som tro och presentera religioner utifrån mallen mannen, boken, tron förankrat i protestantisk kristen tradition är en tradition där också läsning och förståelse av bibeln som enda auktoritet har speciell betydelse (Rasmussen och Thomassen, 2007, s. 283). Denna protestantiska mall har dock också betydelse vid jämförelser, där Koranen uppfattas som samma typ av text och ha samma funktion som Bibeln som inom kristna traditioner (Berglund, 2014a). Båda är så klart böcker och kan därför jämföras som sådana; de har en gemensam berättelse och gemensamt persongalleri, men vad som är viktigt att komma ihåg och som bidrar till förståelsen för dess funktion inom respektive religion är att de befinner sig på olika platser i förhållande till det fenomen som kallas Gud. Följande illustration visar vad jag menar:

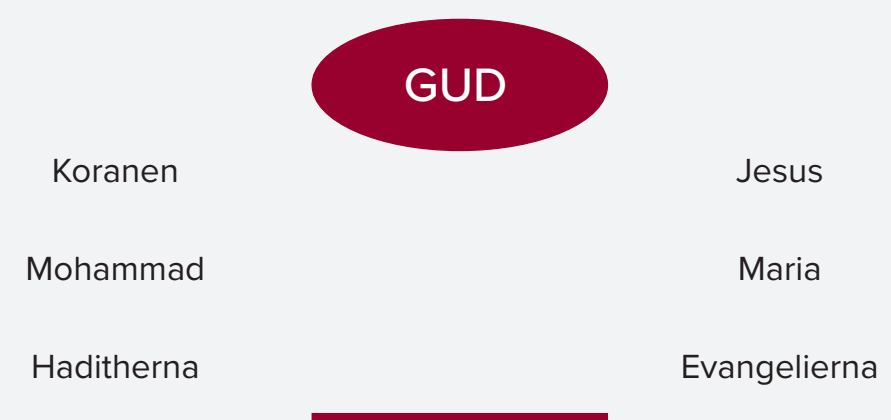

\section{Människor}

Figur 8.1.

Enligt gängse muslimsk förståelse är Koranen Guds direkta ord till mänskligheten på ungefär motsvarande sätt som Jesus uppfattas som Guds ord som blev människa: "uppenbarad i köttet". Jesus kom till mänskligheten genom Maria och

2 Se också Nilsson, 2018, s. 123. 
Koranen genom Mohammad. Om denna förmedlingsprocess kan vi läsa i evangelierna respektive haditherna.

I ett land vars religionshistoria domineras av protestantisk kristendom har många människor en mångfald av bilder som de associerar till kristendom. Dessa bilder är både positiva, negativa eller ibland tämligen neutrala. När en bild på en skrikande pastor som menar att homosexuella ska brinna i helvetet dyker upp i media, så vet många att denna åsikt finns inom ramen för det vi kallar kristendom, men att den inte är dominerande i Sverige eller Norge eftersom de också har en mängd bilder av präster som absolut inte har denna åsikt. När det visas en bild på en ilsken imam som ondgör sig över samma fenomen, saknas dock alternativa bilder och denna bild blir lätt den enda som associeras till islam i relation till homosexualitet.

Ett mycket grundläggande religionsvetenskapligt faktum, som såväl lärare, som andra, bör ha i åtanke är att vad som står i en religiös urkund säger väldigt lite om vad människor gör eller tänker. Olika religioner har klart olika teologier, olika föreställningar, olika värden. Vad som är viktigt är dock inte vad en viss helig bok, eller heliga texter, "säger" (och böcker kan faktiskt inte tala) utan hur människor läser och tolkar dessa texter. Att läsa en religiös text som en polisrapport, det vill säga bokstavligen, förekommer, men det har genom historien inte varit och är inte det gängse sättet. Tolkningar av texter är kopplade till det sammanhang som den tolkande parten befinner sig i. Utöver de etablerade tolkningstraditionerna (till exempel lagskolorna ${ }^{3}$ inom islam) spelar faktorer som tid, plats, etnicitet, kön, sexualitet och socioekonomisk bakgrund roll för utfallet (Ambjörnsson \& Fazlhashemi, 2017).

\section{ETT ALTERNATIV}

Som lärare kanske du nu funderar över alternativ till skolboksmässiga presentationer av religioner. Det finns naturligtvis flera lösningar. Ett alternativ till mallen, mannen, boken och tron är att använda sig av The Three B's of Religion: Believe, Belong and Behave (Berglund \& Gent 2017). Jag väljer här att översätta dessa till tro, tillhöra och göra (TTG). I det följande kommer jag att presentera islam utifrån denna TTG-modell.

3 Traditionellt brukar fem lagskolor (även kallat rättsskolor, madhähib på arabiska) lyftas fram: Hanafi, Maliki, Hanbali och Shafi inom sunni islam och Jafari inom Shia. Inom lagskolorna har den praktiska tillämpningen av sharia utvecklats genom historien. 


\section{Tro}

Självklart är trosdimensionen viktig inom islam. Ofta lyfts de sex trosartiklarna fram (tro på Gud, änglar, böckerna, Profeterna, tro på domens dag och predestination). Den traditionella källan till denna gruppering av sex grundläggande trosartiklar går tillbaka till profeten Muhammad själv och den så kallade Gabrielhadithen (Olsson \& Sorgenfrei, 2015, s. 42). Hadither är korta (men kan också vara längre) berättelser om vad Mohammad och hans närmaste följeslagare gjorde eller sade. Dessa berättelser är betydelsefulla eftersom de, utöver Koranen, utgör de främsta, men inte enda, källorna till islamisk lag. Här finns anledning att åter notera att det trots en mycket stark idé om enhet i tron, också finns en empirisk synlig mångfald. Vissa shiamuslimer lyfter till exempel fram vad de brukar beteckna som fem principer om tro, nämligen: Guds enhet, gudomlig rättvisa, profetuppgång, gudomvalda ledare (imamah) och domens dag. Som vi kan se, finns ett tydligt överlapp. Särdraget hos de så kallade tolv-Shia, ${ }^{4}$ som är den största av de shiitiska grupperingarna, är imamah - tron att Gud valde imamer efter profeten Muhammad att skydda budskapet samt att göra auktoritativa tolkningar av budskapet (Larsson \& Thurfjell, 2013; Olsson \& Sorgenfrei, 2015).

\section{Tillhöra}

Tillhörighet är viktigt inom såväl islam som andra religioner. Till att börja med brukar inte religiösa personer leva i isolering utan upprätta gemenskaper. Inom ramen för dessa gemenskaper träffas man inte bara för att be eller hålla gudstjänst utan här ingår en mängd olika sociala aktiviteter och variabler som gör att tillhörigheten kan se ut på en mängd olika sätt. Sådana variabler kan till exempel vara vilken lagskola en person tillhör, vilken familjegrupp, vilket språk någon talar, vilken etnicitet en person tillhör, vilket land man bor i, huruvida en person tillhör en minoritet eller majoritetssamhället, huruvida personer lever i utanförskap eller innanförskap.

För unga muslimer som lever i väst behöver dock ytterligare faktorer beaktas, även om deras familjer kommer från något av ovanstående sammanhang. Framförallt bör vi beakta hur globaliseringen och den modern tekniken har inverkat (särskilt användningen av sociala medier) på tolkningar av islam (Roy 2006a). Den roll som traditionella muslimska lärde (ulama) hade och fortfarande har som

4 Shiaislam är samlingsnamnet på de islamiska traditioner som menar att det rättmätiga ledarskapet efter profeten går vidare i arv bland Alis ättlingar. Genom historien har det dock uppstått tvister om vem som var den sista rättmätige imamen. Detta har lett till framväxten av en rad olika shiitiska grupperingar. Den största bland de shiitiska grupperna är tolv-shia, imamiterna. 
experter på frågor om hur en muslim idealt sätt bör agera i en viss situation utmanas i dag när unga och andra via internet kan hitta svar på sina frågor långt ifrån den geografiska plats de befinner sig på. Inom muslimska familjer i väst ser vi ibland att den äldre generationen agerar som beskyddare av "traditionell" muslimsk kultur, och att ett generationsglapp utvecklas mellan äldre och yngre medlemmar (Fleischman 2011). För att ta ett exempel från en intervju som nyligen genomförts i ett pågående forskningsprojekt så uttryckte en muslimsk pojke i London att han och hans syskon drogs mer och mer mot salafismen eftersom han menade att många av de saker som hans föräldrar associerade med islam hade mer att göra med pakistansk kultur än islam (Berglund \& Gent, 2017). Den salafistiska varianten av islam har av Olivier Roy förklarats som en del av en global väckelsetrend som tenderar att se det som möjligt att frikoppla religion från kultur till förmån för litteralistisk förståelse och upplevelse av tro. Roy beskriver situationen som:

a consequence of the globalization and Westernization of Islam. Today's religious revival is first and foremost marked by the uncoupling of culture and religion, whatever the religion may be. This explains the affinities between American Protestant fundamentalism and Islamic Salafism: both reject culture, philosophy and even theology in favour of scriptural reading of the sacred texts and an immediate understanding of truth through individual faith, to the detriment of educational and religious institutions. (Roy, 2006b, s. 131)

Utöver de traditionella sätten att tolka islam utifrån lagskolor och den moderna salafistiska trenden finns också andra moderna tolkningsmöjligheter. Bland dessa märks bland annat olika liberala och feministiska tolkningar (se t.ex. Hafnor Bøe 2019; Kurzman, 1998; Olsson \& Stenström, 2011). Vi får inte heller glömma bort alla de som känner tillhörighet till islam men som inte är religiöst eller teologiskt motiverade. Personer som kanske firar de muslimska högtiderna, betecknar sig som muslimer, men som inte relaterar vare sig livs- eller vardagsval till islam. Även bland dessa muslimer finns variation. Kanske motiveras valet att inte äta griskött utifrån islam medan valet att dricka alkohol i stället har att göra med en viss typ av livsstil där detta passar in. Även här kan fokus på levd religion ge såväl lärare som elever en fördjupad förståelse för människors handlanden, tankar och känslor för att undvika främmandegöranden som kan bidra till fördomar och diskriminering. Det etnografiska förhållningssättet handlar om att utveckla elevernas kunskap om religion och livsåskådning på ett sätt som gör att eleverna blir uppmärksamma på hur människor inom olika religiösa traditioner lever med, och uttrycker, sin reli- 
gion och tro på olika sätt (Berglund 2014b; 2020). Det är dock tydligt att minoritetsstatus i ett icke-muslimskt land tvingar fram reflektion över religiös identitet, även hos de som kanske inte är så intresserade eller nödvändigtvis tänker så mycket på att de är muslimer (Otterbeck, 2010).

\section{Göra}

Även om det inom islam finns gemensam praktik, som exempel vissa ritualer, är det viktigt att uppmärksamma att praktik också ser olika ut och skiljer sig mellan människor. Inom islam, som i alla religioner, finns ett brett spektrum av praktik. På ena sidan av detta spektrum finns de som är djupt formade av ett starkt engagemang för islam, medan vi på andra sidan hittar de som ärvt sin muslimska identitet och har begränsat engagemang för de övertygelser och beteenden som traditionellt kan vara förknippade med islam. En annan faktor som bidrar till mångfalden av praktik är det subtila sätt på vilket muslimsk lag utvecklats (Hjärpe, 2014). Inom ramen för islamisk lag differentieras inte bara mellan vad som är rätt och fel. I stället finns en gradering av fem kategorier med avseende på en handling: obligatorisk, rekommenderad, tillåten, ogillad och förbjuden (Olsson \& Sorgenfrei, 2015). Vilken kategori en speciell handling (t.ex. rökning) hör till kan skilja sig mellan lagskolor. När olika experter på islamisk lag ombeds att ge ett utlåtande (fatwa) om en speciell handling, ger de också något (eller ibland mycket) olika svar (det finns ingen central myndighet med makt att göra ett utlåtande som gäller alla muslimer) (Hjärpe, 2014).

\section{RAMADAN SOM KONKRET EXEMPEL}

För att vi verkligen ska förstå betydelsen av tolkning inom religionernas värld behövs konkreta exempel. I det följande kommer jag därför att presentera exempel från hur elitidrottare resonerar kring efterlevnaden av fasta och andra krav under Ramadan. Elitidrottande är ett rikt studiefält för de som är intresserade av att studera mångfalden av tillvägagångssätt som muslimer väljer när det gäller fastan under Ramadan (Alpert 2015).

Sommar-OS 2012 tjänar som vårt första exempel på variation i förhållande till fasta under Ramadan, då olympiska spelen 2012 inträffade under just månaden Ramadan. Faktum är, att muslimska lärde från flera muslimska majoritetsländer gjorde uttalanden som gjorde det möjligt för idrottare att helt avstå från att fasta under de olympiska spelen även om det fanns andra som menade att fastan skulle upprätthållas från gryning till dess att solen gått ner på traditionellt sätt. De tolk- 
ningar som möjliggjorde att helt avstå från fastan baserades på förlängningar av de juridiskt sanktionerade standardundantag som förekommer från att avstå från mat och dryck under dygnets ljusa timmar under Ramadan. Undantagen innebär att att barn, sjuka, gravida, ammande samt att de som är på resande fot inte behöver fasta. Sheikh Abdelmoti Bayumi (ansluten till Al Azhar University i Kairo, Egypten) hävdade dessutom att eftersom de muslimer som är professionella elitidrottare har sin idrott som jobb och inkomstkälla som försörjer deras familjer är det legitimt för dem att bryta fasta när det stör eller försvårar deras "jobb" (Jendoubi 2012). Andra muslimska lärde hävdade att standardundantaget för resor kunde tillämpas på de olympiska spelen eftersom de flesta muslimska idrottare behövde resa till London för att delta. Dessa expertutlåtanden till trots, fanns det självklart också många muslimer som hellre ville förlita sig på sin egen bedömning i frågan huruvida de skulle fasta när OS och Ramadan sammanföll.

Ett exempel på denna senare kategori är Nadia Nadim, även känd som Danmarks svar på Zlatan Ibrahimovic och dotter till en afghansk general som avrättades av talibanerna (Hardenberger 2015). Hon började sin fotbollskarriär med att spela på åkrarna bredvid det flyktingläger hon tillbringade sina första år i Danmark innan hon blev välkänt danskt fotbollsproffs. Nadia har fattat beslutat att fasta på träningsdagar, men inte på matchdagar. "Jag vet att min kropp inte klarar det", säger hon, eftersom vätskebalans och näringsintag påverkar hennes prestation (Ahmed 2017; Virk 2019). Nadim är inte bara professionell fotbollsspelare, hon studerar också medicin. Således tar hon i sitt beslut om när hon ska fasta och inte hänsyn till sin kunskap och sina erfarenheter från såväl fotboll och medicin som islam.

Med Nadia Nadim som exempel önskar jag också knyta tillbaka till frågan om maximalistiska kontra mer vardagliga former av religiös praktik. Nadia Nadim representerar i det här kapitlet muslimer, som antingen är genomsnittliga eller minimala anhängare av islam - dvs. "den vanliga, vardagliga majoriteten", trots hennes inte så vanliga karriär. Hennes berättelse pekar dessutom på en av modernitetens centrala särdrag: individens framträdande plats utöver gruppen. I våra moderna samhällen är det individen, mer än gruppen eller familjen, som förväntas fatta beslut i stora och små frågor. Tordis Borchgrevink hävdar till och med att förmågan att välja är en "grundläggande moralisk kategori" i västerländska samhällen (Borchgrevink 1997: 31). Dessutom har flera forskare noterat att det sätt på vilket unga västerländska muslimer självständigt konstruerar sin inställning till att vara muslim tenderar att spegla den moderna västerländska civilisationens dominerande tro på jaget (Jacobsen 2010). När unga muslimer betraktar sin muslimska identitet som ett personligt val snarare än ärftlighet, bekräftar de både individens 
makt och friheten att välja, som är så mycket en del av det moderna projektet. I en artikel från 2009, ställer Samuli Schielke (2009:37) en viktig fråga: "What happens when claims and ideals come to be practiced as guidelines in a life that has other, competing orientations and is characterized not by the primary purpose of perfection but rather by a struggle to find one's place in life?" Denna fråga antyder indirekt det faktum att representationer av islam som enbart lyfter fram engagerade utövare som formar sina liv i förhållande till fromhet, moral och självdisciplin blir problematiska. Problemet är att de allra flesta muslimer, liksom de allra flesta människor, ibland, men inte alltid, är fromma, ibland men inte alltid moraliska, ibland, men inte alltid, självdisciplinerade. De deltar ibland, men inte alltid, i moskén, ibland, men inte alltid, läser de sina böner, ibland, men inte alltid, firar de högtider och så vidare (Wilander 2019, s. 47-55). Ofta återspeglas dock inte denna typ av ambivalens och inkonsekvens i diskussioner om religion och religiositet.

För att bredda vår förståelse kan det vara av värde att gå utanför den dedikerade utövarens standardområde och undersöka hur muslimer praktiserar sin religion i samband med vardagliga sociala, yrkesmässiga och kulturella aktiviteter - hur de relaterar till fenomen som inte är direkt associerade med deras religiösa tradition (som i fallet med professionell fotboll). Tanken är att genom att göra det kan både lärare och deras elever lära sig något vidare om det moraliska och religiösa universum som de flesta muslimer bebor, viktig information som alltför lätt förblir fördunklad när endast dominerande religiösa metoder syns.

Med tanke på dessa olika överväganden, vad lärde vi oss av Nadia Nadim, vår företrädare för den majoritet av muslimerna för vilka islam bara är en viktig aspekt av ett mångfacetterat liv? Trots det värde som hon lägger på sin muslimska identitet är Nadim, i modernitetens anda, inte en person som fattar personliga val uteslutande baserat på andras råd, vare sig den personen är en äldre, en tränare, en medspelare eller till och med en imam. Snarare anser hon att hennes beslut angående Ramadan och andra aspekter av religiös praxis är hennes egna. Hon ser sig själv som en fri och oberoende spelare som tar ansvar för sina handlingar. Hon tycks, utifrån de intervjuer som finns tillgängliga, vara bekväm med de kompromisser hon har gjort för att balansera sin identitet som muslim med andra viktiga aspekter av sitt liv. Hon tycks helt enkelt vara tillfreds med sina val, möjligen för att hennes framgång och berömmelse som professionell fotbollsspelare har tagit hennes karriär till en mycket hög status vad gäller hennes liv och självbild. Detta kan naturligtvis inte sägas om alla "vanliga" muslimska utövare, vars livserfarenheter och relationer med islam är så olika som man kan förvänta sig.

Exemplet med Nadia Nadim ger dock en ögonblicksbild av hur en muslim balanserar utövandet av sin religion med skyldigheter och ansvar som är av mer 
sekulär karaktär. Utöver Nadim finns mängder av exempel på genomsnittligt hängivna muslimer i alla samhällsskikt som funderar över och löser samma slags frågor som Nadim mötte - att balansera sitt engagemang för islam med sitt engagemang för studier, fotboll och värderingar i samhället. Eftersom många muslimer har motsvarande engagemang för sin religion som Nadia Nadim, är det oerhört viktigt att lärare ger en balanserad bild av muslimsk praxis som minimerar de maximalistiska representationer som för närvarande finns i både media och samhället i stort.

\section{FÖRÄNDRING OCH UTVECKLING}

De empiriska exempel som jag har diskuterat ovan visar den variation som kan förekomma vad gäller Ramadan på två nivåer: det visar dels på den tolkningsvariation som kan förekomma bland muslimskt lärde men också på hur en individ (Nadia Nadim) på ett personligt plan och utifrån sin egen kunskap och identitet förhåller sig till den muslimska fastan. Genom ett empirinära studium av levd muslimsk praktik kan vi förstå att islam, liksom andra religioner, formuleras av människor i relation till sitt sammanhang och är långt ifrån statiska fenomen. Ur ett undervisningsperspektiv är det viktigt att inte bara lyfta fram och presentera denna variation utan också visa på den logik som ligger bakom skillnader och förändring. Jag menar att ett vists mått av religionsvetenskaplig kunskap om hur tolkningsprocesser fungerar i relation till konkreta exempel motverkar essentialistiska och stereotypa bilder av islam. Detta är viktigt inte bara för att undervisningen i skolan ska vila på vetenskaplig grund utan också för att det möjliggör igenkänning och förståelse. Att visa på tolkningsvariation inom olika religioner kan motverka fördomar och xenofobi bland dem som inte tillhör den ena eller andra religionen.

\section{LITTERATUR}

Ahmed, S. (2017). Here is How 15 Hardcore Athletes Train During Ramadan. BuzzFeedNews: https://www.buzzfeednews.com/article/shireenahmed/athletes-fasting-during-ramadan.

Alpert, R. (2015). Religion and Sports: An Introduction and Case Studies. New York: Colombia University Press.

Ambjörnsson, R. \& Fazlhashemi, M. (2017). Visdomens hus: Muslimska idévärldar 600-2000. Stockholm: Natur \& Kultur.

Ammerman, N.T. (2016). Lived Religion as an Emerging Field: An Assessment of its Contours and Frontiers. Nordic Journal of Religion and Society, s. 83-99. 
Asprem, E. (2021) Religionssociologiska perspektiv. I Introduktion till religionshistoriens teori och metod. (red.) Asprem, E \& Sundquist, O. Lund: Studentlitteratur.

Axner, M. (2015) Representationer, stereotyper och nyhetsvärdering - Rapport från medieanalys om representationer av muslimer i svenska medier. Stockholm: Diskrimineringsombudsmannen.

Berglund, J. \& Sorgenfrei, S. (Red.). (2009). Ramadan: En svensk tradition. Lund: Arcus Förlag.

Berglund, J. (2013). Swedish religion education: Objective but marinated in Lutheran Protestantism? Temenos, 49(2), s. 165-184.

Berglund, J. (2014a). Vad är religion i svenska religionskunskapsböcker? Religion \& Livsfrågor, nr. 3, s. 6-8.

Berglund, J. (2014b) An ethnographic eye on religion in everyday life. British Journal of Religious Education, 36 (1), s. 39-52).

Berglund J. (2017) Secular normativity and the religification of Muslims in Swedish public schooling, Oxford Review of Education, 43(5), s. 524-535.

Berglund J. \& Gent B. (2017) Believing, belonging and behaving: some considerations when teaching about Islam. REtoday, The magazine for the Religious Education community.

Berglund, J. (2020) Widening Our Scope from "Maximalists" to More Ordinary Practitionars? I Kvinnligt religiöst ledarskap: En vänbok till Gunilla Gunner. (red. S. Sorgenfrei \& D. Thurfjell). Huddinge: Södertörn Studies of Religion. Hämtad 10. oktober 2020: http://sh.diva-portal.org/smash/get/diva2:1469209/FULLTEXT04.pdf.

Berglund, J. (2021) Religionsdidaktiska perspektiv. I Introduktion till religionshistoriens teori och metod. (red.) Asprem, E \& Sundquist, O. Lund: Studentlitteratur.

Borchgrevink, Tordis (1997). Et ubehag i antropologien. Norsk Antropologisk Tidsskrift (1), s. 2636.

Bossius, T. (2003) Med framtiden i backspegeln: black metal- och transkulturen: ungdomar, musik och religion i en senmodern värld. Göteborg: Daidalos.

Brusi, F. \& Sorgenfrei, S. (2011, 28. augusti). Ramadan i tid och otid. Tidningen Kulturen.

Cotter, C. \& David R. (2016). After World Religions: Reconstructing Religious Studies. Abingdon: Routledge.

Cusack, C. (2016). Complex Learning and the World Religions Paradigm: Teaching Religion in a Shifting Subject Landscape. I After World Religions: Reconstructing Religious Studies, (red.). Christopher Cotter \& David Robertson. Abingdon: Routledge.

Farstad, M.H. (2017) Fra Sami Yusuf til Harris J - Om islamiske verdier og tematisering av muslimsk identitet gjennom halal-pop. Prismet Forskning, 68 (1/2), s. 115-131.

Fleischman, F. (2011) Second-generation Muslims in European Societies. Ridderprint.

Gardell, M. (2010). Islamofobi. Stockholm: Leopard Förlag.

Hafnor Bøe, M. (2019) Feminisme i islam. Universitetsforlaget.

H. Britton, T. (2019) Att möta det levda: möjligheter och hinder för förståelse av levd religion i en studiebesöksorienterad religionskunskapsundervisning. Stockholm: Stockholms universitet.

Hardenberger, M. (2015). Hon är Danmarks svar på Zlatan Ibrahimovic. KvällsPosten: https:// www.expressen.se/kvallsposten/sport/hon-ar-danmarks-svar-pa-zlatan-ibrahimovic/.

Hjärpe, J. (2014). Sharia: Gudomlig lag i en värld i förändring. Lund: Studentlitteratur. 
Hjärpe, J. (2012) Perspektiv på islamologin: essentialism eller religionsantropologi?, I Islamologi: Studiet av en religion (red.). Jonas Otterbeck och Leif Stenberg. Stockholm: Carlsson. S. 265279.

Hylén, T. (2012) Essentialism i religionsundervisningen: Ett religionsdidaktiskt problem. Nordidactica (2): s. 106-137.

Härenstam, K. (2006) En granskning av hur religion/trosuppfattning framställs i ett urval av läroböcker. Underlagsrapport till Skolverkets rapport "I enlighet med skolans värdegrund?": https://www.skolverket.se/download/18.6bfaca41169863e6a6582a8/1553961646011/Religion.pdf (hämtad 2021-04-01).

Jacobsen, C. (2010). Islamic Traditions and Muslim Youth in Norway. Leiden: Brill.

Jendoubi, C. (2012). Muslim Olympians Face Ramadan Dilemma. Nuqudy.

Kittelman Flensner, K. (2015). Religious education in contemporary pluralistic Sweden. Doctoral dissertation. Gothenburg: Gothenburg University.

Kurzman, C. (1998). Liberal Islam: A sourcebook. New York: Oxford University Press.

Larsson, G. \& Thurfjell, D. (2013). Shia-muslimer i Sverige - en kortfattad översikt. SST:s skriftserie, Nr. 3. Stockholm: Nämnden för statligt stöd till trossamfund. Hämtad från: http://www.myndighetensst.se/download/18.373f439f14832abd2cf2d9a9/1409663377272/ Shia-muslimer+i+Sverige_komplett.pdf

Larsson, G. \& Sorgenfrei, S. (2019) Religion. Stockholm: Liber.

Lincoln, B. (2006). Holy Terrors: Thinking About Religion After September 11. London: The University of Chicago Press.

Malik, K. (2014, 14. augusti). Is there something about Islam? Eurozine.

McGuire, M. B. (2008). Lived religion: faith and practice in everyday life. New York: Oxford University Press.

Mutalib, H. (2008) Islam in Southeast Asia. ISEAS: Yusof Ishak Institute.

Nesbitt, E. (2011) The Teacher of Religion as Ethnographer. The Oxford Handbook of the Sociology of Religion.

Nilsson, S. (2018) Det oförutsägbara klassrummet - utmaningar och möjligheter. I Interkulturell religionsdidaktik: utmaningar och möjligheter, Olof Franck och Peder Thalén (red.). Lund: Studentlitteratur, s. 109-130.

Olseryd, J.; Wallin, L. \& Repo, A. (2021) Islamofobiska hatbrott. Rapport 2021:3. Stockholm: Brottsförebyggande rådet.

Olsson, S. \& Sorgenfrei, S. (2015). Islam: En religionsvetenskaplig introduktion. Stockholm: Liber.

Olsson, S. \& Stenström, H. (2011). Levande ord - Tolkningar av abrahamitiska källtexter. Lund: Studentlitteratur.

Otterbeck, J. (2005). What is Reasonable to Demand? Islam in Swedish Textbooks. Journal of Ethnic and Migration Studies, 31: 95-812.

Otterbeck, J. (2010). Samtidsislam: Unga muslimer i Malmö och Köpenhamn. Stockholm: Carlssons.

Otterbeck, J. \& Bevelander, P. (2006). Islamofobi: En studie av begreppet, ungdomars attityder och unga muslimers utsatthet. Stockholm: Forum för levande historia. 
Owen, S. (2011). The world religions paradigm. Time for a change. Arts and Humanities in Higher Education: An International Journal of Theory, Research and Practice 10(3), s. 253-268.

Panjwani, F. (2017). No Muslim is just a Muslim: Implications for education. Oxford Review of Education, 43(5), s. 596-611.

Panjwani, F. \& Revell, L. (2018). Religious education and hermeneutics: the case of teaching about Islam, British Journal of Religious Education, 40:3, 268-276.

Pickel, G. och Öztürk, C. (2018). Islamophobia Without Muslims? The "Contact Hypothesis" as an Explanation for AntiMuslim Attitudes - Eastern European Societies in a Comparative Perspective. Journal of Nationalism, Memory \& Language Politics, Online, Vol. 12 (2): 162-19.

Rasmussen, T. \& Thomassen, E. (2007) Kristendomen. Skellefteå: Artos \& Norma bokförlag.

Roy, O. (2006a) Globalized Islam - The search for a new Umma. New York: Columbia University Press.

Roy, O. (2006b). Islam in Europe: Clash of religions or convergence of religiosities? I M. Krzysztof (Red.), Religion in the New Europe Budapest: Central European University Press, s. 131144.

Schielke, S. (2009). Being good in Ramadan: ambivalence, fragmentation, and the moral self in the lives of young Egyptians. Journal of the Royal Anthropological Institute, s. 24-40.

Sorgenfrei, S. (2018). Islam i Sverige. Stockholm: Myndigheten för stöd till trossamfund.

Thurfjell, D. (2016). Det gudlösa folket: De postkristna svenskarna och religionen. Stockholm: Molin \& Sorgenfrei.

Toft, A. (2018) Inescapable News Coverage: Media Influence on Lessons about Islam. I Knut Lunby (red.). Contesting Religion. The Media Dynamics of Cultural Conflicts in Scandinavia. Berlin/Boston: DeGruyter.

Toft, A. (2019) Conflict and entertainment: Media Influence on Religious Education in Upper Secondary School in Norway. MF Norwegian School of Theology, Religion and Society.

Tägt, A. (2018) Undervisningsfilm i religionskunskap: En granskning av hur judendom, kristendom och islam framställs i undervisningsfilmer som används i religionskunskap. Examensarbete: Stockholms universitet.

Virk, Z. (2019). Denmark: Afghan Refugee Nadia Nadim Scales Summit of Women's Football. The Muslim Times: https://themuslimtimes.info/2019/03/21/denmark-afghan-refugee-nadia-nadim-scales-summit-of-womens-football/.

Wilander, E. (2019) Sveriges religiösa landskap: samhörighet, tillhörighet och mångfald under 2000-talet. Stockholm: Myndigheten för stöd till trossamfund.

Wright, A. (2004). Religion, education, and post-modernity. London \& New York: Routledge/ Falmer. 